\title{
Wirus nieszczęścia. Plagi i choroby domu Lenartowiczów w dobie epidemii cholery w XIX-wiecznej Europie
}

\section{The Misery Virus: Plagues and Diseases in the Lenartowicz Family during the $19^{\text {th }}$-Century Cholera Epidemic in Europe}

Summary: The cholera epidemic originating from the Ganges Valley reached Europe in the 1830 s, only to plague the continent in successive bouts until the end of the century. The disease decimated the population and harrowed European physicians, though - surprisingly - not many contemporary sources describing the epidemic have been preserved. One of the few surviving accounts can be found in the letters of Zofia Lenartowicz née Szymanowska, who was travelling around Europe with her husband during the 1865 cholera outbreak. The 1860s were a particularly difficult period for Zofia and Teofil Lenartowicz. Their distress stemmed from their chronic destitution, which in turn exacerbated the suffering caused by the medical maladies experienced by both spouses. In view of this overall misery, the threat of cholera was far from the greatest worry of the Lenartowicz couple, which found a clear reflection in the content of the letters discussed in the present paper.

Keywords: Teofil Lenartowicz, Zofia Lenartowiczowa, cholera epidemic, Italy, $19^{\text {th }}$ century

Streszczenie: Epidemia cholery, mająca swoje źródło w Dolinie Gangesu, dotarła do Europy w latach trzydziestych XIX wieku, by nawiedzać ją regularnie do końca stulecia. Zaraza dziesiątkowała ludzkość i spędzała sen z oczu medykom, jednak - co zaskakujące - nie zachowało się wiele relacji z epoki na temat epidemii. Jedną z nich można znaleźć w korespondencji Zofii z Szymanowskich Lenartowiczowej, podróżującej z mężem po Europie w 1865 roku, podczas kolejnego wybuchu cholery. Lata sześćdziesiąte XIX wieku były okresem wyjątkowo trudnym dla Zofii i Teofila Lenartowiczów. Pierwszą przyczyną zmartwień małżonków była ustawiczna bieda, potęgująca cierpienia wynikające z chorób, które nękały oboje. W obliczu tych nieszczęść zagrożenie cholerą nie stanowiło największego zmartwienia Lenartowiczów, co znajduje odzwierciedlenie w omawianych listach.

Słowa kluczowe: Teofil Lenartowicz, Zofia Lenartowiczowa, epidemia cholery, Włochy, XIX wiek 
Głównie zajmującym teraz umysły przedmiotem jest cholera, o której wszędzie wiadomo - nie wesoły przedmiot a dla wielu - mianowicie dla szczęśliwców tego świata jest to miecz Damoklesa, wiszący nad głową, którego ciąłe przypomnienie ścina uśmiechy najpowabniejsze, pobledza najróżowsze policzki, odbiera w okamgnieniu apetyt najzawołańszym gastronomom, a mąci najpoetyczniejsze marzenia wszelkim romansowym głowom. W podobnych chwilach ci, co w ludzkiej rodzinie do najnieszczęśliwszych się liczą, są właśnie szczęśliwszymi, bo ich ta ogólna plaga najmniej zatrważa - nie mają czego tak dalece żałować i łatwiej im wyglądać bliskiej śmierci ${ }^{1}$.

Przytoczony wyżej fragment listu Zofii Lenartowiczowej do Teodory z Narbuttów Monczuńskiej, pisanego w Szwajcarii jesienią 1865 roku, stanowi jedną z niewielu wzmianek w korespondencji Lenartowiczów na temat epidemii cholery azjatyckiej - plagi, która regularnie nawiedzała Europę w XIX wieku. Po raz pierwszy przywędrowała z Indii do Rosji w 1831 roku $^{2}$ i szybko rozprzestrzeniła się wśród innych państw europejskich, by zadomowić się na kontynencie do końca stulecia ${ }^{3}$.

Cholera nie tylko stanowiła poważne zagrożenie dla zdrowia i życia tysięcy ludzi, ale i powodowała utrudnienia w codziennej egzystencji, z którymi nie każdy łatwo się godził. Środki prewencyjne, przedsiębrane w celu zapobieżenia rozprzestrzenianiu się zarazy, spotykały się z oporem - najważniejszym z nich już od XVII wieku była kwarantanna, stosowana wobec załóg i ładunków statków przypływających do Europy z Bliskiego Wschodu ${ }^{4}$. Przeciwnikami restrykcji byli przedstawiciele kupiectwa, którzy widzieli w nich poważną przeszkodę dla swoich interesów.

Problem konfliktu między zasadą wolnego handlu a potrzebą kontroli granic pojawił się już podczas pierwszej fali epidemii. Cholera bardzo szybko przedostała się do podzielonej Polski, zbiegając się z ruchem rewolucyjnym, który spędzał sen z powiek zaborcom - na tyle, że obawa przed zarazą zeszła na dalszy plan ${ }^{5}$. Szybko jednak problem epidemii musiał zostać potraktowany priorytetowo najpierw przez armię rosyjską, dziesiątkowaną przez epidemię ${ }^{6}$,

List Zofii Lenartowiczowej do Teodory z Narbuttów Monczuńskiej z 1 października 1865 roku [w:] H. Biegeleisen, Żona poety, Warszawa 1933, s. 30.

2 K. Turcza, Trucizna jako lek - czyli sposoby leczenia cholery w dziewiętnastowiecznym Krakowie, „Farmacja Polska” 2018, nr 74 (1), s. 10. Zob. też: A.G. Carmichael, Cholera: zaraza pandemiczna [w:] Wielkie epidemie w dziejach ludzkości, red. K.F. Kiple, tłum. E. Boyé, Z. Sidorkiewicz, M. Słomczyński, Poznań 2002, s. 207.

3 A.G. Carmichael, dz. cyt., s. 207-215.

4 Mediterranean quarantines, 1750-1914, red. J. Chircop, F.J. Martinez, Manchester 2018, s. 110.

5 R.S. Ross, Contagion in Prussia 1831: The Cholera Epidemic and the Threat of Polish Uprising, Jefferson, North Carolina 2015, s. 9.

${ }_{6}$ Tamże, s. 80. 
a następnie przez władze pruskie, obawiające się napływu uchodźców z Kongresówki po powstaniu listopadowym. Wdrożono środki ostrożności, polegające między innymi na zwiększeniu kontroli na granicy rosyjsko-pruskiej, strzeżonej odtąd przez wojsko, wprowadzono także obowiązkową kwarantannę, co miało przy okazji stanowić sposób rozwiązania problemu politycznych uciekinierów z Królestwa Kongresowego, szukających azylu w zaborze pruskim7. Ten, kto naruszył zasadę poddania się kwarantannie i nielegalnie przekroczył granicę, miał zostać natychmiast zastrzelony. Powyższe regulacje wzbudziły rzecz jasna kontrowersje zwłaszcza wśród mieszczaństwa ${ }^{8}$.

Kwestia wprowadzenia obowiązkowej kwarantanny dla zagranicznych jednostek pływających we wszystkich państwach europejskich z dostępem do morza była dyskutowana w 1851 roku podczas pierwszej Międzynarodowej Konferencji Sanitarnej w Paryżu, która nie doprowadziła jednak do ratyfikowania przygotowanej wówczas konwencji, mówiącej o konieczności przestrzegania jednolitych zasad izolacji w celu zapobiegania rozprzestrzenianiu się chorób zakaźnych? Do podpisania pierwszej konwencji sanitarnej, dotyczącej środków kwarantanny morskiej dla okrętów przypływających do Europy z Bliskiego Wschodu, doszło dopiero w roku 1892 podczas siódmej konferencji w Wenecji ${ }^{10}$. Niemniej już wcześniej władze poszczególnych krajów wprowadzały wewnętrzne regulacje, mające zapobiegać rozprzestrzenianiu się cholery. O tym, jak uciążliwe wydawało się to podróżującym po Europie, świadczą dalsze słowa Lenartowiczowej z cytowanego wyżej listu do Monczuńskiej, wyrażające obawę przed utrudnieniami, czekającymi małżonków podczas powrotu ze szwajcarskiego Vevey do Florencji (miejsca zamieszkania Lenartowiczów):

W istocie już od paru tygodni, dzięki Bogu, zaczyna się polepszać zdrowie Teofila i myślę, że za dni kilkanaście będziemy w drodze, do Florencji. Podróż w tamte strony krzyżują nam trochę wieści o cholerze, bo Teofil, nie mogąc jechać dyliżansem, dla cierpienia w boku, musi morzem płynąć. Pomijając to, iżbyśmy jechali na Marsylię, gdzie cholera jest dotąd, powstrzymuje nas głównie perspektywa kwarantanny w Liworno. Może też Bóg da, że za parę tygodni już się plaga uśmierzy ${ }^{11}$.

Rzeczywiście, już w czerwcu 1865 roku władze Zjednoczonego Królestwa Włoch wydały zarządzenie o obowiązkowej siedmiodniowej kwarantannie dla statków egipskich, zakazując jednocześnie odstąpienia od kwarantanny w portach morskich wyposażonych w szpitale, w przypadku stwierdzenia obecności

7 Tamże, s. 43, 56-57, 221.

8 Tamże, s. 11.

9 Mediterranean quarantines, 1750-1914, dz. cyt., s. 20-21.

10 J. Barcik, Międzynarodowe prawo zdrowia publicznego, Warszawa 2013, s. 7.

11 List Zofii Lenartowiczowej do Teodory z Narbuttów Monczuńskiej z 1 października 1865 roku, dz. cyt., s. 29. 
chorych lub zmarłych na przypływających statkach - na zastosowanie tych środków ostrożności szczególnie nalegał konsul włoski w ogarniętej epidemią Marsylii ${ }^{12}$. Obawy Lenartowiczowej były zatem całkowicie uzasadnione. Uderzające, że bardziej niż ryzyko zakażenia cholerą Lenartowiczów martwiły uciążliwa podróż i kwarantanna w porcie. Być może należy to wiązać z nihilistyczną wręcz postawą życiową obojga, wyrażoną tak dobitnie we fragmencie listu Zofii cytowanym na początku. Życie małżonków we Florencji naznaczone było bowiem ustawiczną biedą i licznymi chorobami nękającymi oboje. Obraz tych nieszczęść nakreślił Lenartowicz w liście do Tekli Zmorskiej z 17 czerwca 1867 roku:

W moim namiocie nędznym, bo nie w domu, smutek aż do kości. Samotność i ból. Żona mi choruje od dwóch lat na piersiową chorobę, która rozwijać się poczęła przeszłej jesieni i dziś już jest tak, że jej długiej egzystencji wróżyć nie można. Doktorzy egzaminowali piersi i powiedzieli mi wyraźnie: że jest źle. Kaszle wciąż i chudnie coraz bardziej i siły traci i poty ją oblewają, słowem że jest choroba, a nie niedomaganie. Pracować nie może, wygód potrzebuje, a tu znikąd grosza jednego. (...) Do tego ze zdrowiem jestem tak, że w zimie nieustające febry żółciowe. Utrata głosu zupełna, bezsenność, stan najopłakańszy, sił żadnych. W lecie lepiej, ale niewiele, chodzić nie mogę, kaszlę także, i nie gadam ${ }^{13}$.

Istotnie w tym czasie siły Zofii podupadły na tyle, że nie potrafiła już utrzymywać siebie i męża, jak czyniła to dotąd, udzielając lekcji muzyki, języków, rysunku i kaligrafii ${ }^{14}$ czy sprzedając swoje prace malarskie we Włoszech i w Polsce. Czuła się odpowiedzialna za byt obojga, o czym świadczy chociażby jej list do Józefa Ignacego Kraszewskiego z lutego 1868 roku, w którym prosi go o wsparcie w rozpowszechnianiu prac rzeźbiarskich Lenartowicza, mających być nowym źródłem utrzymania małżonków; jednocześnie usprawiedliwia się, że sama zbyt podupadła na zdrowiu, aby zarobić na nich dwoje ${ }^{15}$. Kilka lat wcześniej, po śmierci jedynego syna Lenartowiczów Jana ${ }^{16}$, poeta zaprzestał pisania przysparzało mu zbyt wiele wzruszeń, w związku z czym zostało mu wzbronione przez lekarzy. Niespodziewanym lekarstwem na zbolałą psyche okazała się

12 A. Pongetti, Società e colera nell'Italia del XIX secolo. L'epidemia di Ancona del 1865-67, Milano 2009, s. 62-63.

13 List Lenartowicza do Zmorskiej z 17 czerwca 1867 roku [w:] Listy Teofila Lenartowicza do Tekli Zmorskiej 1861-1893, z autogr. wydała, wstępem i przyp. opatrzyła J. Rudnicka, posł. S. Szwalbe, Warszawa 1978, s. 54.

${ }_{14}$ Zob. A. Melbechowska-Luty, Lenartowiczowa Zofia [w:] Stownik artystów polskich i obcych w Polsce dziatających. Malarze, rzeźbiarze, graficy, t. 5: Le-M, red. J. Derwojed, Warszawa 1993, s. 34 .

15 [Listy Zofii Lenartowiczowej do Józefa Ignacego Kraszewskiego], Biblioteka Jagiellońska, rp. 6515 IV, k. 368.

16 M. z Przeździeckich Walewska, Polacy w Paryżu, Florencji i Dreźnie, Warszawa 1930, s. $87-88$. 
praca fizyczna, w tym wypadku - próby rzeźbiarskie (a mówiąc ściślej: modelarskie, bo była to praca w glinie, nie w kamieniu), o których wspominała Zofia w rozmowach z Marią z Przeździeckich Walewską:

pewien nasz znajomy rzeźbiarz ${ }^{17}$ odwiedzający go [Lenartowicza - dop. M.B.B.] niekiedy, widząc, jak sztuki plastyczne lubi, jakim jest ich znawcą i miłośnikiem przyniósł mu pewnego razu trochę gliny, aby pod jego kierunkiem coś lepił - ot tak dla rozrywki. Ta pierwsza robota tak mu się znakomicie udała, że zachwycił swego mistrza ${ }^{18}$.

Prace rzeźbiarskie Lenartowicza, mimo że chwalone i nagradzane na wystawach we Florencji i w Wiedniu, nie przynosiły jednak spodziewanych zysków. Zofia po krótkiej rekonwalescencji nad morzem (skąd przysłała zresztą do męża list pożegnalny, sądząc, że jej dolegliwości zakończą się śmiercią) ${ }^{19}$ przystąpiła zatem ponownie do pracy: pomagając Teofilowi w dystrybucji artykułów i rzeźb, jednocześnie sama wciąż malowała. W czerwcu 1870 roku wybrała się do Poznania w poszukiwaniu nabywców swoich obrazów ${ }^{20}$. Niestety zaraz po przyjeździe na miejsce jej stan zdrowia bardzo się pogorszył, toteż jej gospodarze - państwo Sewerynostwo Mielżyńscy - zabrali ją do uzdrowiska w Miłosławiu. Tam Zofia stwierdziła znaczną poprawę, którą przypisywała zbawiennej mocy wód Vichy oraz wpływowi miejscowego powietrza:

Dr Świderski kazał mi pić wody Vichy i najczcigodniejsza p. Mielżyńska, której dobroci dość wypowiedzieć nie mogę, wyszukała mi w swojej apteczce wody Vichy. Zaczynam czuć wpływ tutejszego, doskonałego powietrza, a po miesiącu pobytu odreperuję się najzupełniej ${ }^{21}$.

Niebawem jednak objawiła się u Zofii niedrożność jelit i zapalenie otrzewnej, które ostatecznie doprowadziło do jej śmierci 8 lipca 1870 roku $^{22}$. Niepocieszony Lenartowicz dwa tygodnie później pisał do szwagra Zofii, Jana Leszczyńskiego:

17 Mowa zapewne o Giovannim Dupré, uznanym rzeźbiarzu florenckim, który przyjaźnił się z Lenartowiczem i wspierał jego działalność rzeźbiarską. Por. list Lenartowicza do Kraszewskiego z 19 marca 1868 roku [w:] Korespondencja. J.I. Kraszewski, T. Lenartowicz, oprac. W. Danek, Warszawa 1963, s. 125.

18 M. z Przeździeckich Walewska, dz. cyt., s. 88.

19 Zob. H. Biegeleisen, dz. cyt., s. 32-33, 64.

20 Tamże, s. 40.

21 List do Teofila, pisany z Miłosławia 18 czerwca 1870 roku [w:] H. Biegeleisen, dz. cyt., s. $55-56$.

22 H. Biegeleisen, dz. cyt., s. 57, 63, 71. 
Choroba jej była nie dzisiejszą, do Rzymu przyjechała cierpiąc na piersi, w kilka lat później egzaminujący ją doktor mówił mi, że się formowały tuberkuły w płucach, to się uspokoiło, ale następnie rozpoczęło się wyniszczenie organiczne, diarie wciąż się powtarzające, a mianowicie w gorąca i chłody większe, diarie te próbowały już psucia się organów digestywnych, żołądek nie funkcjonował tyle prawie co nic i żółć tylko wyrabiała się nieustająco, pomimo nawet, że nie było powodu do zmartwień i że miłość, jaką ją otaczałem i szacunek powszechny pomiędzy Włochami wszystkimi, którzy ją znali, dawali jej to zadowolenie, które nam starczy za wszystko. (...) Trzy lata temu wywiozłem ją nad morze dla powietrza i wówczas moja najukochańsza, w Bogu żyjąca, małżonka napisała do mnie list, (...) w którym żegnając się na wieczną drogę i przewidując śmierć swoją, popisała mi o miłości naszej i wiecznym związku. (...) Z Poznania mi teraz piszą, że uleczoną być nie mogła, że wnętrzności pełne były wrzodów i że czy w domu, czy za domem, to, co nastąpiło, nastąpićby musiało ${ }^{23}$.

Kilka lat wcześniej, w roku 1865, gdy Lenartowiczowie podróżowali po Europie, ponownie opanowywanej falą cholery, oboje byli już w fatalnej kondycji fizycznej: Teofila dręczyły choroba krtani ${ }^{24}$, kamica nerkowa, anemia ${ }^{25}$, a Zofia cierpiała na gruźlicę ${ }^{26}$, dodatkowo musiały ich osłabiać środki, zażywane dla uśmierzenia bólu, do których zaliczały się belladonna (wilcza jagoda) i arszenik ${ }^{27}$. Małżonkowie byli przy tym chronicznie niedożywieni i mieszkali w złych warunkach, pracowali ponad siły, przeżywali też w tym czasie śmierć nowo narodzonego dziecka. Wszystkie wymienione doświadczenia czyniły ich, jak określiła Zofia, „najnieszczęśliwszymi w rodzinie ludzkiej”, wyczekującymi rychłej śmierci ${ }^{28}$, co znajdowało odbicie między innymi w korespondencji Lenartowicza z Kraszewskim z tego okresu:

Choroba moja chroniczna, bronchitowa, w skutku grypy, czyli fluksji piersiowej, jaka tu panowała, rozwinięta, tak mnie pięknie postawiła. Co robić, trzeba sobie wyperswadować żywot długi i marzenie o szczęściu jakimś tam na świecie, widzenia czegoś poczciwego i przyjąć, co palec boży zaznaczył. (...) Już było niby trochę lepiej, jużem się cieszył słońcem, bo Bóg świadkiem, że czym innym cieszyć się nie mam, taka wkoło mnie i nas pustka, takie tu zimno jakieś wieje od ludzi, i naraz skończona historia, znowu poty zimne, znowu zaduszania po nocach, znowu głowa ciąży i nogi włóczyć się nie mogą, i w oczach ćmi się, i w gardle zasycha. (...) Żona

3 Tamże, s. 64-65.

24 Zob. Korespondencja. J.I. Kraszewski, T. Lenartowicz, dz. cyt., s. 93.

25 Tamże, s. 100.

26 Zob. List Lenartowicza do Zmorskiej z 17 czerwca 1867 roku, dz. cyt.

27 List Lenartowiczów do Anieli i Jana Leszczyńskich z 4 stycznia 1868 roku [w:] H. Biegeleisen, dz. cyt., s. 35.

${ }^{28}$ List Zofii Lenartowiczowej do Teodory z Narbuttów Monczuńskiej z 1 października 1865 roku, dz. cyt. 
moja również na piersi się skarży i doktorzy nakazują jej, jak będzie mogła najprędzej, wyjeżdżać nad morze, dobra rada, ale gdzie i czy tam znajdziem aby jedną duszę żywą, która by się o chorych dwoje zainteresowała? (...) Jeśli tej wiosny przyjdzie wędrować do lepszych światów, wspominajcie czasem² ${ }^{29}$.

Do niedomagań natury fizycznej dochodziły zatem cierpienia psychiczne, samotność i tęsknota za rodzinną ziemią, „od której z daleka ciężko żyć, ale za to umierać łatwo przychodzi” ${ }^{30}$. W obliczu tylu nieszczęść, wprowadzających do życia Lenartowiczów atmosferę rezygnacji, problem rozprzestrzeniającej się epidemii musiał im się zdawać mało znaczący, choć znali przypadki zachorowań w rodzinie Zofii: na cholerę zmarli przecież pianistka Maria Szymanowska, pierwsza żona ojca malarki, a także Adam Mickiewicz, ożeniony z przyrodnią siostrą Zofii Celiną.

Warto nadmienić, że zakaźność i złośliwość cholery była często lekceważona przez współczesnych. By pozostać przy przykładzie Mickiewicza, wystarczy wspomnieć szkic literacki Rozmowy chorych, powstały w wyniku kontaktu poety z dotkniętymi cholerą w Burgas lub w Konstantynopolu w roku $1855^{31}$ czyli w roku śmierci wieszcza. Ów krótki dialog między chorym pułkownikiem i jego adiutantem ukazuje obserwacje Mickiewicza dotyczące objawów zakażenia, a także jego zdystansowany stosunek do epidemii. Wystarczy przytoczyć kwestię pułkownika, oskarżającego swojego rozmówcę o otrucie: „to ty ze swoim francuskim doktorem doprowadziłeś mnie do tej cholery. Przez całe życie nigdy nie byłem chory! Sprowadziłeś mi doktora i te proszki, które doprowadziły mnie do tej cholery" 32 . Prawdopodobnie mowa tu o proszku Dovera, zawierającym $10 \%$ opium, sproszkowany korzeń wymiotnicy i korzeń mleczny, która to mieszanka miała wywoływać torsje, według ówczesnej wiedzy medycznej - zbawienne dla pacjenta ${ }^{33}$. Jednocześnie wymioty pozostawały jednym z charakterystycznych objawów cholery, stąd aluzja w wypowiedzi pułkownika.

Szkic Mickiewicza, humorystyczny i zakończony wyzdrowieniem pacjenta, pokazuje, że poeta mógł sobie nie zdawać sprawy ze zjadliwości i zaraźliwości cholery. Z pewnością nie dysponował wiedzą o sposobie rozprzestrzeniania się choroby: choć już w 1848 roku angielski epidemiolog John Snow zaobserwował zależność między szerzeniem się cholery a zanieczyszczonym fekaliami

29 List Lenartowicza do Kraszewskiego z 2 lutego 1867 roku [w:] Korespondencja. J.I. Kraszewski, T. Lenartowicz, dz. cyt., s. 109-111.

30 Tamże, s. 109.

31 Zob. D. Świerczyńska, Mickiewiczowskie „Rozmowy chorych”, „Pamiętnik Literacki” 1994, nr 85 (2), s. 150-153.

32 A. Mickiewicz, Rozmowy chorych [w:] tenże, Proza artystyczna. Opowiadania, szkice, fragmenty, wstęp i oprac. J. Pietrzak-Thébault, Warszawa 2013, s. 501.

33 K. Turcza, dz. cyt., s. 11. 
ujęciem wody, z którego korzystali zakażeni ${ }^{34}$, natomiast zaledwie sześć lat później włoski lekarz Filippo Pacini wyodrębnił bakterię cholery, to dopiero w 1883 roku vibrio cholerae został opisany przez niemieckiego uczonego Roberta Kocha ${ }^{35}$. W czasach Mickiewicza i Lenartowicza wciąż z powodzeniem funkcjonowała teoria miazmatów, czyli „wyziewów gnilnego powietrza pochodzących z wnętrzności ziemi i wdzierających się do ciała" ${ }^{36}$, które miały powodować choroby zakaźne, takie jak cholera czy dżuma ${ }^{37}$. Potwierdza to wydana w 1866 roku we Lwowie broszurka autorstwa doktora Józefa Chądzyńskiego, w której pisał on o cholerze, że:

pierwiastkowo może to być żywioł pochodzący z wyziewów szkodliwych moczarowatych, ale potrzebuje dla swego rozwoju żywego organizmu, że w nim się odnawia, z nim się przenosi, czy to z wojskiem, czy z pielgrzymami lub pojedynczymi osobami ${ }^{38}$.

Autor zaznaczył, że „ścisłe, mądrze wykonane kwarantanny (...) są w stanie oprzeć się złemu, powstrzymać epidemię" ${ }^{39}$. Doktor przyjął także tezę o zaraźliwości cholery, kwestionowaną jeszcze w tym czasie przez wielu mimo doświadczeń z poprzednich fal zarazy, które zalały Europę ${ }^{40}$. W tym samym roku redagowana przez Kraszewskiego „Gazeta Polska” opublikowała oparte na odkryciach Snowa zalecenia higieniczne rządów Niemiec i Wielkiej Brytanii, mające chronić przed cholerą i doradzające zachowanie szczególnej ostrożności „organizmom wycieńczonym wiekiem, nadużyciami, nędzą i strachem” ${ }^{41}$.

Wszystkie wymienione okoliczności były udziałem Lenartowiczów, co czyniło ich wyjątkowo podatnymi na zakażenie, które ich jednak ominęło. $Z$ uwagi na to, że poza przytoczonym listem Zofii do Monczuńskiej nie zachowały się żadne relacje małżonków mówiące o cholerze, należy przyjąć, że w obliczu licznych nieszczęść i osobistych przypadłości epidemia nie wydawała im się największym zagrożeniem. Listy Lenartowicza do Kraszewskiego wypełnione są szczegółowymi opisami dolegliwości, dręczących poetę i jego żonę, pojawiają się w nich również opinie na temat bieżących wydarzeń, zatem brak jakiejkolwiek wzmianki na temat cholery wydaje się zastanawiający.

Uwzględniając jednak fakt, że żadne z małżonków nie padło ofiarą zarazy, a także biorąc pod uwagę sytuację polityczną Europy tego okresu, która

34 Zob. M. Gańczak, John Snow i cholera - 200-lecie urodzin, „Przegląd Epidemiologiczny” 2014, nr 68, s. 169-170.

35 K. Turcza, dz. cyt., s. 14-15.

36 Tamże.

37 Por. A. Pongetti, dz. cyt., s. 29, a także: M. Gańczak, dz. cyt., s. 169.

38 J. Chądzyński, Cholera wr. 1865, Lwów 1866, s. 4.

39 Tamże, s. 4-5.

40 Tamże, s. 6.

41 S. Janikowski, Przegląd higieniczny, „Gazeta Polska” 1866, nr 197, s. 2. 
stanowiła główny przedmiot dyskusji Lenartowicza z korespondentami, pominięcie w jego wypowiedziach nawracającego problemu cholery jest wytłumaczalne. Nie należy zapominać, że kolejne epidemie, wybuchające w latach trzydziestych, czterdziestych i sześćdziesiątych XIX wieku, nakładały się na wydarzenia polityczne wielkiej wagi. Ruchy rewolucyjne, w Polsce powstanie listopadowe, a później styczniowe, w międzyczasie rzeź galicyjska, we Włoszech walki wyzwoleńcze, zakończone powstaniem Zjednoczonego Królestwa w 1861 roku - te kwestie zaprzątały Lenartowicza bardziej aniżeli kolejna fala cholery. Poeta nie był w tym zresztą odosobniony, wystarczy przytoczyć wyjątek z jednego z listów jego stałego interlokutora Kraszewskiego:

Nie mamy się czym dziś dzielić, jeno nędzą naszą. Gdyby ona była jak największa, nie byłaby jeszcze tak dotkliwa, jak jest przy zupełnym ducha rozstroju i upadku. (...) Pamiętam dobrze stan po 1831 roku, ale porównania nie ma wyczerpania i bezsilności, jak nie ma porównania ucisku, który dziś jest, z mikołajowskim, cynizmu nawet, z jakim się on dopełnia. (...) A tymczasem... emigracja teraźniejsza, nędza wszelaka mrze z głodu i z tęsknoty pozdycha. Mnóstwo wraca choćby pod miecz. Coś okropnego jest w tej obojętności ${ }^{42}$.

Lenartowicz odpowiedział Kraszewskiemu: „Największą plagą naszego kraju jest fałsz” ${ }^{33}$. Za prawdziwą zarazę stulecia poeta uważał obojętność i brak solidarności narodów (zarówno polskiego, jak włoskiego), powszechny marazm i degenerację społeczeństw ${ }^{44}$. Absorbowały go tragiczne dzieje kolejnych powstań i ciężki los Sybiraków, osłabienie ducha patriotycznego w Polakach po klęsce 1863 roku i postępujące później umocnienie stronnictwa konserwatystów w narodzie ${ }^{45}$. Wydaje się, że w połączeniu z osobistymi nieszczęściami, dotykającymi Lenartowiczów między rokiem 1861 (gdy zawarli małżeństwo) a 1870 (rokiem śmierci Zofii), wymienione problemy musiały wyprzeć strach przed epidemią cholery, dziesiątkującą ludzkość nie po raz pierwszy i nie ostatni w tym niespokojnym stuleciu.

${ }^{42}$ List Kraszewskiego do Lenartowicza z kwietnia 1865 roku [w:] Korespondencja. J.I. Kraszewski, T. Lenartowicz, dz. cyt., s. 93-94.

43 List Lenartowicza do Kraszewskiego z 26 marca 1860 roku [w:] Korespondencja. J.I. Kraszewski, T. Lenartowicz, dz. cyt., s. 68.

${ }^{4}$ T. Lenartowicz, [Z Florencji], „Tydzień Polityczny, Naukowy, Literacki i Artystyczny” 1870, R. 1, nr 6, s. 56-57 oraz nr 12, s. 110.

45 Zob. List Lenartowicza do Kraszewskiego z 9 kwietnia 1869 roku [w:] Korespondencja. J.I. Kraszewski, T. Lenartowicz, dz. cyt., s. 130-131. 


\section{Bibliografia}

Barcik J., Międzynarodowe prawo zdrowia publicznego, Warszawa 2013.

Biegeleisen H., Żona poety, Warszawa 1933.

Carmichael A.G., Cholera: zaraza pandemiczna [w:] Wielkie epidemie w dziejach ludzkości, red. K.F. Kiple, tłum. E. Boyé, Z. Sidorkiewicz, M. Słomczyński, Poznań 2002.

Chądzyński J., Cholera w r. 1865, Lwów 1866.

Gańczak M., John Snow i cholera - 200-lecie urodzin, „Przegląd Epidemiologiczny" 2014, nr 68.

Janikowski S., Przeglad higieniczny, „Gazeta Polska” 1866, nr 197.

Korespondencja. J.I. Kraszewski, T. Lenartowicz, oprac. W. Danek, Warszawa 1963.

Lenartowicz T., [Z Florencji], „Tydzień Polityczny, Naukowy, Literacki i Artystyczny" 1870 , R. 1, nr 6, 12.

Listy Teofila Lenartowicza do Tekli Zmorskiej 1861-1893, z autogr. wydała, wstępem i przyp. opatrzyła J. Rudnicka, posł. S. Szwalbe, Warszawa 1978.

[Listy Zofii Lenartowiczowej do Józefa Ignacego Kraszewskiego], Biblioteka Jagiellońska, rps 6515 IV, k. 367-369.

Mediterranean quarantines, 1750-1914, red. J. Chircop, F.J. Martinez, Manchester 2018.

Melbechowska-Luty A., Lenartowiczowa Zofia [w:] Stownik artystów polskich i obcych $w$ Polsce dziatajacych. Malarze, rzeźbiarze, graficy, t. 5: Le-M, red. J. Derwojed, Warszawa 1993.

Mickiewicz A., Proza artystyczna. Opowiadania, szkice, fragmenty, wstęp i oprac. J. Pietrzak-Thébault, Warszawa 2013.

Pongetti A., Società e colera nell'Italia del XIX secolo. L'epidemia di Ancona del 186567, Milano 2009.

Ross R.S., Contagion in Prussia 1831: The Cholera Epidemic and the Threat of Polish Uprising, Jefferson, North Carolina 2015.

Świerczyńska D., Mickiewiczowskie „Rozmowy chorych”, „Pamiętnik Literacki” 1994, nr 85 (2).

Turcza K., Trucizna jako lek - czyli sposoby leczenia cholery $w$ dziewiętnastowiecznym Krakowie, „Farmacja Polska” 2018, nr 74 (1).

Walewska z Przeździeckich M., Polacy w Paryżu, Florencji i Dreźnie, Warszawa 1930. 